\title{
The Social Impacts of War: Agency and Everyday Life in the Borderlands during the Early Seventeenth Century
}

\author{
Martina Hjertman ${ }^{1}$ • Sari Nauman ${ }^{1}$. \\ Maria Vretemark ${ }^{2} \cdot$ Gwilym Williams $^{3}$. \\ Anders Kjellin ${ }^{4}$
}

\author{
Published online: 5 April 2017 \\ (C) The Author(s) 2017. This article is published with open access at Springerlink.com
}

\begin{abstract}
In this paper, we address some of the social impacts of war, including issues of negotiating identity during displacement caused by war. What it meant to be Swedish or Danish-Norwegian in a town where there was a not insubstantial population of foreign merchants would clearly be an ambiguous situation. Burghers were elected by fellow citizens, who were themselves from other parts of Sweden, Scandinavia, and Northern Europe, including Germany, Holland, England, and Scotland. Allegiances were contingent, and in many cases among aliens probably more local than national. The social impacts of war in modern-day west Sweden extended beyond the towns directly affected, such as Nya Lödöse and Ny Varberg. The degree to which individuals could act with agency and autonomy was contingent and context-specific. Forced migration and the negotiation of identity are issues that remain relevant today;
\end{abstract}

Martina Hjertman

martina.hjertman@gu.se

Sari Nauman

sari.nauman@gu.se

Maria Vretemark

maria.vretemark@vgmuseum.se

Gwilym Williams

gwilym.williams@riogbg.se

Anders Kjellin

anders.kjellin@arkeologerna.com

1 University of Gothenburg, Gothenburg, Sweden

2 Västergötlands Museum, Skara, Sweden

3 Rio Göteborg Natur- och Kulturkooperativ, Gothenburg, Sweden

4 Arkeologerna, Uppsala, Sweden 
questions of memory, property, trauma, history, and narratives are still debated by combatants and non-combatants. Many of the issues which both civilians and military men and women experienced in the sixteenth- and seventeenth-century wars between Sweden and Denmark-Norway are much the same as in more recent times. The social impacts of war in the seventeenth century were no less than those experienced in the twentieth and twenty-first centuries.

Keywords War $\cdot$ Agency $\cdot$ Borderlands $\cdot$ Migration $\cdot$ Identity $\cdot$ Social impacts $\cdot$ Sweden

\section{Movement during Times of Unrest}

In 1600, Adrian Bann became a burgher of Nya Lödöse, which allowed him among other rights and obligations, the right to trade. When he subsequently married the mayor's daughter, his happiness could hardly have been more complete. However, when the Kalmar War came and during 1611 and 1612, Danish and Swedish troops fought in and around Nya Lödöse, compelling many families to abandon their homes in search for a more peaceful place (Almqvist 1929:5; Larsson and Rosén, forthcoming).

The family of Adrian Bann found refuge in the town of Karlstad, Värmland county, where they stayed until the war ended in 1613. After this, they moved to Mariestad, in the historic county of Skaraborg, and made a good living for themselves. In 1619, after several years in exile, they returned to their former home town Nya Lödöse, and with great effort and cost rebuilt a home. Life back in Nya Lödöse did however not last long: in 1621, Gustav II Adolf founded Gothenburg, and the crown ordered all inhabitants of Nya Lödöse to dismantle their houses and re-erect them in the new town. Adrian Bann was forced to move once again (Almqvist 1929: 5; Larsson and Rosén, forthcoming).

Adrian Bann was just one of many affected by war during this period. The small town of Ny Varberg lay south of Nya Lödöse, in an eastern Danish county, which is today part of the Swedish west coast. The town of Ny Varberg was also subject to the vicissitudes of war. As we show in this article, the people living in the regions around both Nya Lödöse and Ny Varberg were subject to forced movement as well as detention during and shortly after the war. In Foucauldian terms, these events forced the various actors into different subject positions: starting as wealthy burghers, they ended up as refugees and were forced to start again, or alternatively soldiers for whom war ended as prisoners. Sometimes they took a more proactive role in these changes. We will correlate place and movement with agency and subject positions, offering a new understanding of the social impacts of war.

\section{Place and Agency}

The aim of this article is to study the social impact of war. Unlike in battlefield archaeology, our intention is not to ascertain and map the course of events and the places of battles. Rather, the article will discuss how war impacted upon everyday life and the subject positions of people inhabiting towns, fortresses, and the surrounding countryside; we consider the archaeology of displacement and how social and political identities were negotiated during wartime. Border areas, such as the region around 
Swedish Nya Lödöse, were especially exposed during times of conflict. During the early modern era conflicts succeeded each other, and in this article we investigate one of the major conflicts in this area: the Kalmar War (1611-13).

Nya Lödöse was a Swedish town both before and after the war, but was occupied by Danish forces during it. On the other hand, the town of Ny Varberg was located in the Danish kingdom, in Halland, just $80 \mathrm{~km}$ south of Nya Lödöse. Today this county is part of the Swedish west coast, and has been so since the peace treaties of the middle years of the seventeenth century. Both towns are revealing examples of the difficulties in assigning a place and the people living in it a particular nationality during this time; war changed everything in a heartbeat, and there was no way for the respective authorities to guarantee the loyalties of their subjects. Furthermore, the proximity of the towns to one another, their connections in trade and more, as well as their simultaneous exposure to the various wars offers good possibilities for comparison.

Throughout the sixteenth and seventeenth centuries, the inhabitants of Halland experienced political turbulence and a near-constant fear of war. The Northern Seven Years War (1563-70) not only meant attacks on the town Ny Varberg itself, but the war and its aftermaths severely affected the lives of burghers and the rural populace in different ways which are discussed below. In between wars, until the later Kalmar War broke out, it is obvious that the notion of war was continuously present for the population.

The events forced many inhabitants into becoming refugees within their own country. The situation for these people can be viewed in both archaeological and historical sources. As a result, we can present a full picture of the everyday life of war, which in turn can be used to understand the social impact of war in other periods and other geographies.

\section{Landscapes of War}

\section{Nya Lödöse}

The town of Nya Lödöse is situated on the south bank of the river Göta at its confluence with the river Säve, east of the fortresses of Gullberg and, further west downstream, Älvsborg. The archaeological record suggests that a moat and timber palisade were built on the town's south side. Dendrochronological results indicate a felling date in 1528 with a construction date believed to be sometime shortly after this. Apart from some burnt layers, which have proved difficult to interpret, but are believed to represent evidence of Danish razing of the town in 1521, there have been few traces of military activity recovered archaeologically prior to the excavation in 2016.

Earlier excavations carried out by Sixten Strömbom in 1916 (Strömbom 1924), revealed a defensive work in the northern part of the city; here the moat was $20 \mathrm{~m}$ wide and the rampart $2 \mathrm{~m}$ high. More detailed information on this structure can be expected from future investigations to be undertaken in that area in the coming years. In 2015, results from excavations on the south side of the river indicated how the fortifications of the town might have looked, comprising a moat with an internal timber palisade (Fig. 1). There have been some finds of a purely military character from the historic site of Nya Lödöse include various weapons and bullets, although these are largely from the Strömbom investigations at the beginning of the twentieth century. 
These finds are unfortunately out of context, having been recovered during dredging of the river under Strömbom, or from excavations in other unspecified areas.

Some archaeological events have correlating historical records. In the coming years' excavations, the archaeological results will put these historical documents to the test and allow us to develop a more nuanced narrative of both archeological and historical sources.

\section{Ny Varberg}

The town of Ny Varberg was founded some $5 \mathrm{~km}$ north of the center of the present town of Varberg. The oldest written mention of Ny Varberg (Ny Wardhberg) is from 1443 (Sandklef 1963:45). Archaeological investigations seem to corroborate historians' suggestions that the town was established around 1430 (Carlsson 1992a:14). Ny Varberg was placed strategically quite close to the old main road into Västergötland and Småland which crossed the King's Way between Oslo and Copenhagen. Unlike Nya Lödöse, Ny Varberg has never been fully archaeologically examined. The largest investigation was conducted between 1979 and 1983, when a $500 \mathrm{~m}$ long trench, measuring up to $12 \mathrm{~m}$ wide, was dug across the entire length of the 25-ha town, as part of the construction of a new road (Carlsson 1992b:24; Forsström and Sundnér 1973:93).

In addition to this investigation, a few research and trial excavations have also been conducted in parts of the town during the twentieth century. The archaeological investigations have shown how Ny Varberg expanded in the first half of the sixteenth century, with regular, planned plots and streets that extended over the entire town, and built up to its maximum extent by the middle of the sixteenth century (Carlsson 1992b: 23, 1992d:33, 1992e:44). Apart from archaeological data, information about the town can also be adduced from written sources, although, not from before 1565 , since a fire in this year destroyed the city archives in their entirety (Sandklef 1963:197).

The town was located near the sea, at the confluence of two minor rivers, the Munk and the Himle (Munkån and Himleån). On the east side of the town, there were earthworks comprising an internal and external set of ramparts and associated moats at least $700 \mathrm{~m}$ long. The rest of the town was delimited by two sections of the two rivers - Munkån and Himleån - each $450 \mathrm{~m}$ long and were reinforced by an internal rampart ( Forsström and Sundnér 1973:130; Sandklef 1963:111, 113, 204).

Excavations during the 1960s as well as the 1980s have recorded sections through the fortifications, revealing the moats to have been built of blocks of turf and substantial oak timbers. This work has also evidenced repairs as well as wholesale rebuilding, demonstrating two, if not three, construction phases. Dendrochronological dating of tree trunks from a timber palisade illustrate that this was built sometime before 1500 into the side of an older moat.

How efficient and reliable the fortification was, remains questionable. While the early moat was more of a town ditch, later improvements made it up to $20 \mathrm{~m}$ wide in places; the height of the mound is, however, unknown (Carlsson 1992c:28, 1992d:42; Forsström and Sundnér 1973:131f).

It is obvious that the Danish crown did not expect peace to last, since improvements to border defense continued even after the end of the Northern Seven Years War. In 


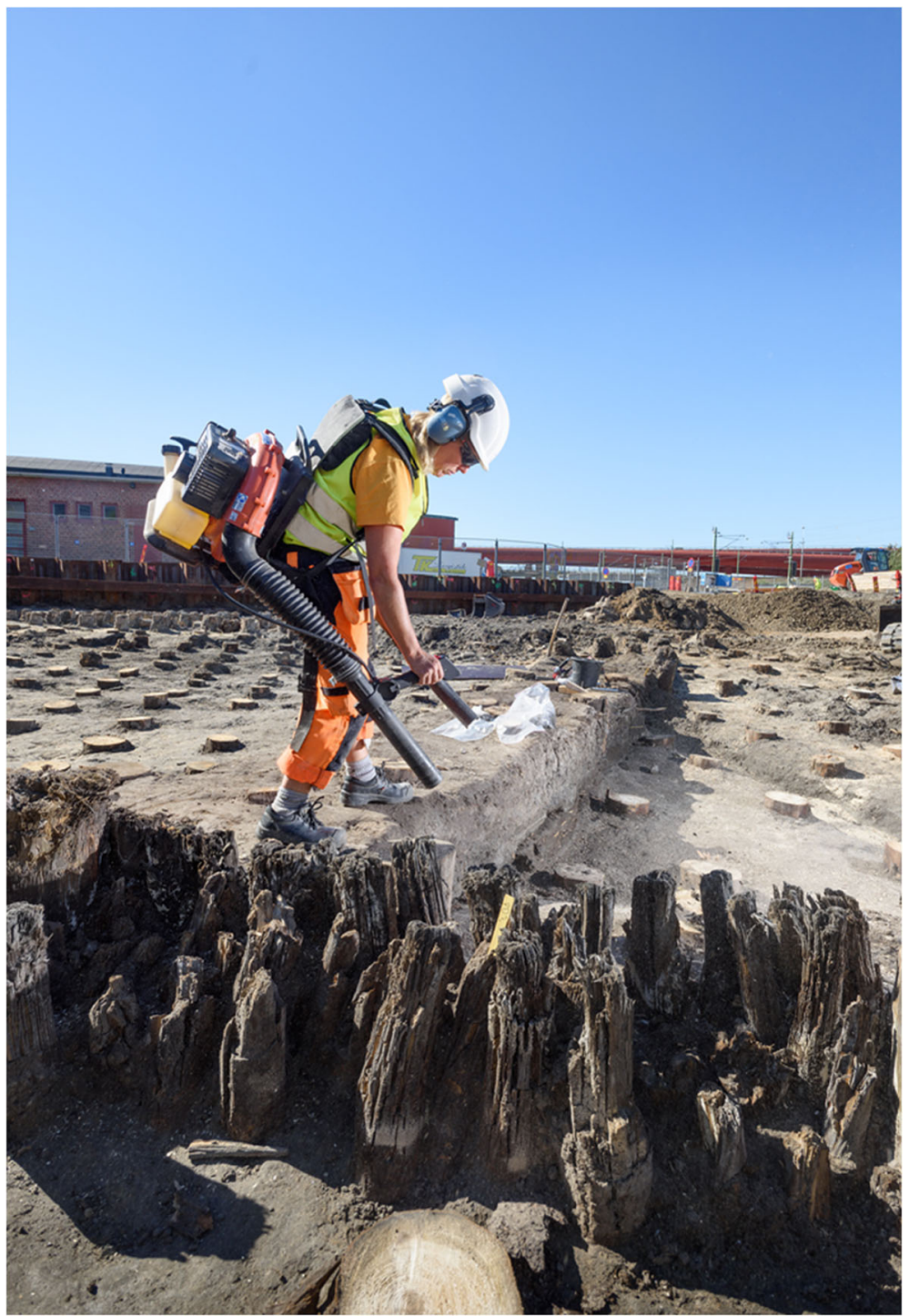

Fig. 1 The palisade, in Nya Lödöse, excavated in 2015. Archaeologist Pia Svensson is cleaning the former moat, later destroyed by modern building activities. Photo: Markus Andersson

1588, the crown started a 30-year-long modernization of Varberg Castle - existing still today in Varberg - turning it into an up-to-date star fort with bastions and casemates that could withstand new types of warfare (Sandklef 1963:271).

The Swedish attack on Ny Varberg in 1612 was not the first in the town's history, but proved to be the last. Documentary sources indicate that Ny Varberg was attacked on the night of February 4, 1612. It is hard to ascertain actual events of that night, but the prevailing opinion is that the town was razed to the ground by fire. However, if one examines the archaeological record from Ny Varberg it is clear that traces of fire are limited (cf. Hjertman and Lundberg, forthcoming). More devastating instead for the 
town seems to have been the fire of 1597, from which the town never recovered properly (Carlsson 1992f:57). The attack however dealt a deathblow to the town, as the burghers were in 1612 ordered by King Christian IV of Denmark to dismantle the remaining houses and move into the shelter of the fortified Varberg Castle. New settlement on the former town land was forbidden (Sandklef 1963:178) and it eventually became farm land.

\section{The Kalmar War}

Danish Christian IV declared war on Sweden in April 1611, and laid siege to the city of Kalmar a month after that. War continued on several fronts on and off during the following two years, and Danish troops advanced as far as Jönköping in the middle of southern Sweden (Norrie and Gordon 1978; Persson 2005: 304-311). The peace treaty of Knäred 1613 upheld the previous boundaries and forced the crowns to restitute all occupied territory. However, Sweden was also to pay a war indemnity over the next six years, and during this time Denmark was given the right to occupy the fortress of Älvsborg, the town of Nya Lödöse, and some parishes between the two.

The west coast was first affected by the war in the summer of 1611. Danish troops occupied Nya Lödöse in June, and in that same month besieged Älvsborg. From that point onwards, the area was constantly contested, up until the decline of hostilities at the end of 1612. The movement of troops and so forth has been thoroughly investigated elsewhere (see for example Sveriges krig 1611-1632 1936; Norrie and Gordon 1978) and is of significantly lesser importance in this paper.

\section{Killed or Slain}

\section{Nya Lödöse}

The physical danger brought about by warfare is one of the most obvious aspects of social impact. Traces of warfare activities that affected individual persons are healed or unhealed wounds, recorded from human skeletal remains. Among the 246 adult individuals buried in the western and southern parts of the churchyard at Nya Lödöse, there were 15 cases of weapon-related violence. The various instances of damage to bones evidence cuts with axes or swords, as well as stabbing and blunt force trauma. While no children experienced these kinds of injuries, this does not necessarily mean that children were not exposed to warfare violence. Lesions in soft tissue are not detectable when only skeletal remains are present (Fig. 2).

Most of the weapons-related violence occurred to men in 14 out of the 15 instances encountered. As the total number of skeletons from adult males (ie., 20 years) in the assemblage is 148 , the prevalence of warfare injuries is at least $9.5 \%$. Eight of the men had healed injuries while six of them had died instantly or shortly after the fatal attack.

For the most part, the traces of weapon violence found on the skeletons from Nya Lödöse are found on the skull. This trauma distribution pattern is often observed in skeletal assemblages from battles (e.g., Kjellström 2003:102; Novak 2000: 98). It seems that the violence was primarily aimed for the head but it could also reflect a situation where the trunk, arms, and legs were better protected when compared to the 


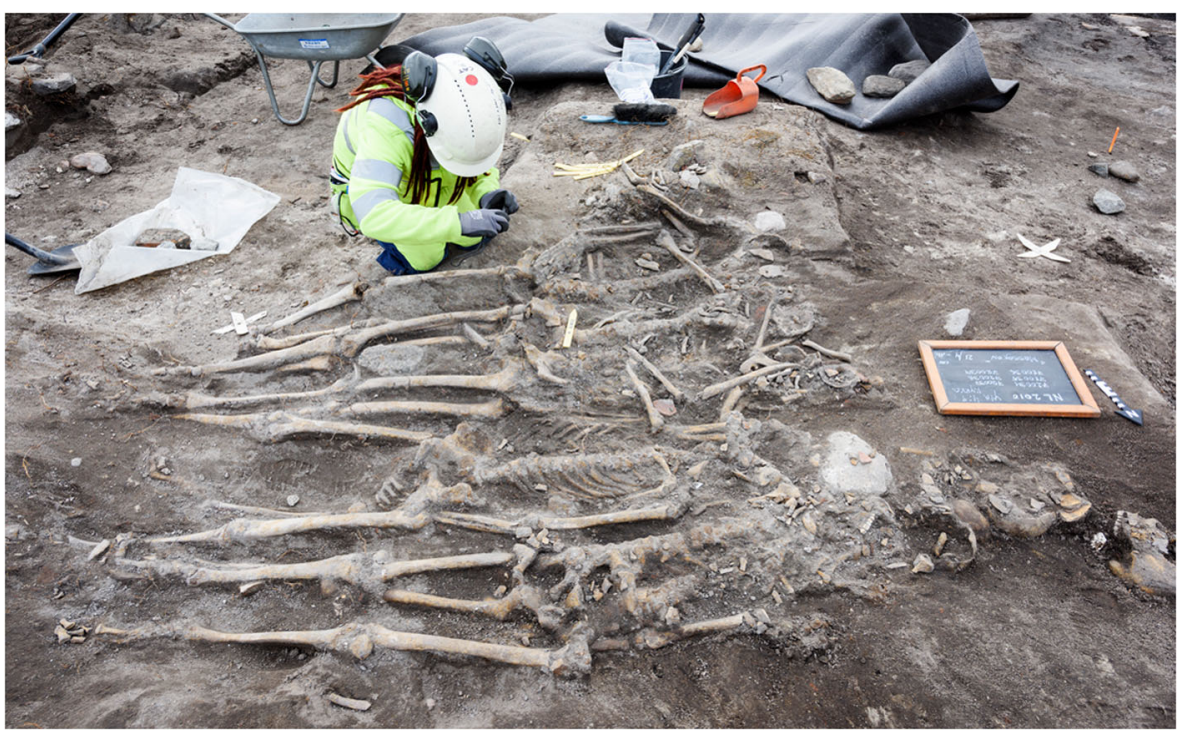

Fig. 2 One of the mass graves from the Nya Lödöse cemetery. Osteologist Cathrine Andersson is excavating the skeletons. Photo: Markus Andersson

head. Another explanation is that the injured men were foot soldiers hit by men on horseback.

The injuries recorded were all results of near-contact violence between the combatants. No traces of injuries caused by distant shooting weapons were identified. Furthermore, most of the injuries were found on the left side of the body. Dominance for left side cuts and blows are typical for battle-related violence (Ingelmark 1939:166). When right-handed soldiers fight each other face-to-face the wounds will most often be located to the left-hand side of the body.

Nevertheless, some exceptions to the dominance of left-side wounds were found in a mass grave of five men. These men had cuts located, for example, over the right ear, in the right temple, in the throat, and in the neck indicating that they were killed, not while fighting face to face, but more likely while lying or sitting on the ground. One of the men had an old healed cut in his skull suggesting that he had experienced warfare earlier in life. The careless burial, with some of the corpses placed in the wrong direction, may indicate the execution of enemy soldiers.

A young woman, 20-25 years of age was the only obviously female victim of weapon violence. At least two fatal cuts were present on the right side of the skull and ear. She was probably attacked from behind, perhaps while trying to escape. This is a striking example of how civilian town dwellers were afflicted by the horrible consequences of war. The assumption that the woman killed was civilian and not military is drawn not from her gender but rather from evidence of disease on her bones. She had advanced pathological changes in all the long bones due to a severe case of osteomyelitis and osteitis (inflammation in the marrow cavity and bone surface). This condition would have reduced her abilities to take part in such military duty or other services that might otherwise have been frequently performed by women in the baggage train in early modern times. 
It is striking how severe the violence appears to have been in most cases of weaponrelated trauma. There are often several cuts or blows as if the outcome of an act of blind rage. The worst example is a 30-40 year old man with at least 11 cuts over his left eye, forehead, and parietal bone. A further example is that of a young man attacked with some kind of stabbing weapon. He had numerous triangular perforations in his head and also on his left underarm, probably as he unsuccessfully tried to protect his body and fend off the attack. Nevertheless, despite the violence of these attacks, the majority of the civil population seems not to have experienced extensive interpersonal violence related to war (Fig. 3).

\section{Ny Varberg}

In 1936, the town church in Ny Varberg was excavated. It lay under part of a royal manor which the former town had become, where it was necessary to build a new barn. Under the church floor 124 graves were discovered, which burials dated from between 1400 and 1565. In a later layer, 13 graves from the period 1565-1612 were revealed. From these skeletons, 90 skulls were selected by two dentists for a caries frequency examination (Sandklef 1963:103, 108-109).

The Carmelite monastery was excavated some 30 years later, in 1964. One hundred and seventy-eight individuals were found, of which 127 were examined odontologically. Of these 127, 101 individuals were from the period 1530-1612, and thus were postReformation burials representing a population other than monks. Remaining individuals were dated to the active period of the monastery, the 1460 s or 1470 s until 1530 . The skeletal examination focused mainly on the individuals' teeth, just as it had regarding remains from the town church. Nevertheless, the two examinations on skeletal material from the town church as well as the Carmelite monastery, also revealed skeletal injuries which had been made by swords or axes (Sandberg 1966).

Recent osteological re-examination of 98 of Sandberg's 127 individuals (36 individuals from the Monastery era before 1530, and 62 individuals from after the reformation1530) confirms traces of violent acts on the skeletons. However, only nine

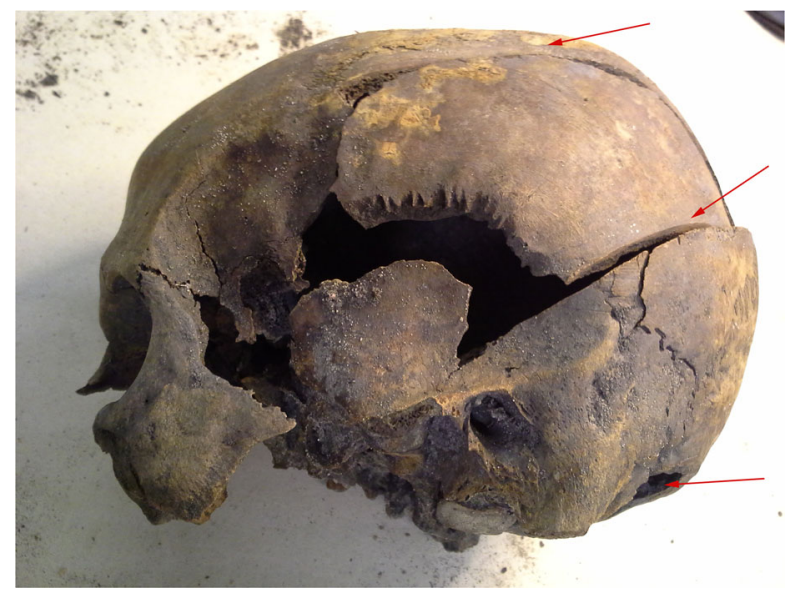

Fig. 3 Left side of cranium from a 40 year old man buried at the cemetery of Nya Lödöse. He was instantly killed by three blows from a sword or an axe (marked with arrows in the picture). Photo M. Vretemark 
individuals (all male) show skeletal trauma that were undoubtedly caused by weaponrelated violence. It would appear that violence was as frequent when the monastery was active, as during the post-Reformation period (Andersson 2013).

However, the skeletons buried during the period 1530-1612 show other interesting traits. Individuals buried when the monastery was active, before 1530, indicate trauma related to hard manual work to a higher degree. The group from after 1530, shows a higher occurrence of diseases related to malnutrition, which may indicate a period of bad harvests or food shortage - what one would expect happen in the footprints of war. Deficiency disease is more common amongst the juvenile skeletons (0-20 years), probably since young person's bodies are more sensitive to fluctuations in nourishment (Andersson 2013). However, most burghers were probably buried in and around the town church, and individuals studied from the monastery church are not representative of the entire town population.

In the 1980s, remnants of what was probably a small chapel dedicated to St. Georg, were discovered some $350 \mathrm{~m}$ south of Ny Varberg. In addition to the chapel foundations, the excavation revealed seven graves plus one pit filled with at least six individuals. In this mass grave one individual had a crossbow arrow buried in its chest and others showed marks of cutting blows. The latest written mention of the chapel is from 1530 and the remains are not archaeologically dated (Ullberg-Loh 1983, 1992). The skeletons could therefore be older than the attacks on Ny Varberg in either 1565 or 1612, but nevertheless bear witness to a longer tradition of violence.

The majority of the populations in and around the towns had their lives changed by war and conflict in other ways than interpersonal weapon-related violence. In the following section, we will present some of those new identities that took form because of the effects of war.

\section{Life in Towns}

\section{Life of Defense}

Professional soldiers were a present and prominent element in both burghers' and farmers' everyday lives. The inhabitants of Ny Varberg had for several periods - during war as well as peace - foot-soldiers and artillerists along with their families and guests billeted upon them. The burghers and peasants around Varberg were also required to supply the soldiers with food and beer (cf. Sandklef 1963: 80, 131, 134, 165, 173). The number of people living in a small town such as Ny Varberg increased during times of conflict burdening the burghers with extra mouths to feed.

In wartime food clearly became hard currency, something that Danish correspondence evidences. During both the Northern Seven Years' War and the Kalmar War provisions were needed at the castle (cf. Sandklef 1963:161, 175), but the region's farmers had great difficulty meeting these kinds of demands. During the Northern Seven Years' War, the rural population was totally destitute, unable to pay their land duties; provisions and succor were sought from other towns in the Danish kingdom (Sandklef 1963:134, 153). Plundered and burnt farms and crops as well as the obligation to supply incoming soldiers created a want of food that affected both farmers and burghers. 
After the Kalmar War, a census was taken of the inhabitants of Varberg county who were not able to meet their tax demands. While this survey only numbers a mere 990 commoners' names, it is important to bear in mind that these persons merely represented their families and farms, which in their turn consisted of several more tenanting households. In reality, far more than 990 persons were thus severely economically affected by the Swedish-Danish conflict. Depending on their location, parishes were also differently subject to plundering soldiers. In Skällinge parish, where Swedish troops encamped in advance of the battle of Kölleryd's heath, the devastation was almost complete and only a few farms escaped pillaging. Areas where large troop movements took place and farms in vicinity of the main road along the coast were naturally more subject to looting by soldiers. However, that some inhabitants, who were previously already destitute, pretended to have been razed and plundered by soldiers in order to get tax exemptions and thereby take advantage of a current situation, is something that might have occurred (Karlsson and Karlsson 2013).

In addition to historical accounts, oral traditions in the shape of common place names may also indicate the intensity of competition for food in war time. Names like "Pork's Hole" (Fläskens hål) and "The Pork Crack" (Fläskaklämman), can still be found in northern Halland, for places said to have been used by peasants as hiding places for food during times of war (Wiking-Faria 2013).

Troop transports and the stationing of soldiers are recognizable to an extent in the documentary sources. Archaeologically we may detect times of hardship through deficiency diseases and weapon violence in skeletal remains, but there are also more tangible traces of soldiery in the form of spurs, ammunition, parts of weapons or other equipment. Following the excavation of a seventeenth-century pottery assemblage from Flanders (Poulain and De Clercq 2015:636) discussion has revolved around whether it might indicate certain dietary practices. The assemblage comprised many small cooking pots that may indicate the heating and consumption of food in individual portions, which is likely for a military context. Such a practice would also have served to form and reinforce the soldiers' group identity.

A unique assemblage of a large quantity of various food- and drink-related items was found in an abandoned water cistern in Ny Varberg in the 1980s. The vessels were deposited in the cistern sometime around the final occupation phase of the town, together with quite large quantities of high status food such as split goat and cattle heads. More than 150 redware vessels - mostly intact - including bowls, plates, frying pans but mainly tripod bowls had been thrown in the cistern. Thirty of these tripod bowls are considered small (up to 0.61 , or approximately one pint) and therefore individual food bowls. The constituent elements of the assemblage points to a plausible interpretation of it as the serving vessels from some form of inn or similar service industry (cf. Hjertman and Lundberg, forthcoming). It is possible that this assemblage evidences the increased need for larger quantities of food and drink, in the form of the archaeological remains of the vessels for preparation and serving, for the billeted soldiers in the town during the Kalmar War.

\section{Construction Workers}

Ny Varberg played an important and strategic role in the Danish kingdom and therefore had to be protected. Several documents from the sixteenth century mention repair to 
and maintenance of those defensive works surrounding the town. A few documents reveal that the mayor, burghers and commoners in Ny Varberg were ordered to rebuild and improve the fortifications. In return they received years of certain tax-exemptions, more favorable taxes on German beer as well as freedom from the obligation to provide men for the army and navy (Sandklef 1963:46, 76, 204).

When the Kalmar War broke out, the Danish king Christian IV found it necessary to improve Ny Varberg's defenses, and ordered the construction of a tranche and mound accompanied with redoubts and flanks. In November 1611, crown tenants in the closest hundreds as well as burghers, were ordered to carry out these improvements. Burghers and some peasants were also trained in warfare, and some farmers had to do military service at Varberg Castle (Sandklef 1963:174-176).

\section{Merchants}

The archaeological material and documentary sources evidence widespread trade throughout the sixteenth century in a range of everyday objects and foodstuffs. It seems to have been common for farmers in the Swedish border regions of Småland and Västergötland to sell oxen to Denmark, which raised concerns for the Swedish king Gustaf I; of particular concern to him was the export trade to Varberg (Sandklef 1963:74).

People from the Danish county of Halland, including burghers from Ny Varberg, also fished the Norwegian waters along the coast of Bohuslän, selling the catch at the fish market in Nya Lödöse among other places. The Danish king forbade this in 1551, ordering the fish to be sold within the kingdom, at St Oluf's market in Varberg (Sandklef 1963:75, 132). The possibility that trade over the Swedish-Danish border continued during the Northern Seven Years' War as well as the succeeding Kalmar War is plausible, but would however then have been illegal. It seems this would be the case at least around the Danish town of Halmstad (Balic et al. 2015:28), located around $70 \mathrm{~km}$ south of Ny Varberg, which was also affected by the Swedish-Danish conflicts.

Officially approved and established trade routes were, of course, impacted by war. At the same time, the burghers from Ny Varberg complained on several occasions of more than one unofficial market place not far from the town. This unofficial commerce even took place within the town limits and in its harbor by non-resident traders. Both Danes and foreigners traded in salt, herring, German beer, clothes, skins and so forth at these black markets (Sandklef 1963:76, 205). Trade was thus taking place and finding new routes outside regulatory control. How trade networks continued, were disconnected or reformed in relation to the Kalmar War, is unclear. What is clear, nevertheless, is that people found both official and unofficial ways to make a living.

\section{Widows}

Of all that is written on the Kalmar War about its soldiers, generals, fortifications, battles and tactics, there remains one seldom discussed casualty — the widow and surviving family. Widowhood was difficult in the seventeenth century, as most of the daily work of a household demanded at least two working parties. Much of the work was divided along gender boundaries, making both a man and woman necessary for upholding the status and the livelihood of the family. In towns and cities, married 
couples often worked in the same trade, and formed a partnership where both parties were necessary for the family's subsistence (Ågren 2013; Ling 2011; Oja 2015).

According to law, a soldier's widow had to go to the consistory court before the bishop and the chapter, in this case located in Oslo, Norway's capital. If a widow wished to remarry she had to submit an application for permission to remarry to the ecclesiastical court, with witnesses to testify that her husband had been killed and that she was therefore free to remarry. As a result of the Kalmar war, a number of declarations of death and applications for permission to remarry were tried at the at Oslo's cathedral chapter between 1614 and 1616. Several such cases can be associated with Nya Lödöse. For example, in March 1614 a deposition was made in which two witnesses stated that they had seen Inger Anders Daatter's husband lying dead on the ice at Nya Lödöse. As a consequence of this statement, she received permission to remarry (Hansson 1977:33).

Other cases evidence the often brutal deaths experienced by soldiers during the war, but also the need for the women applying for such permissions to have surviving witnesses for their cases (Hansson 1977:33). Therefore, the future for the surviving wives depended upon other survivors; tying these disparate lives together even where some of them had moved to the countryside or to other towns. There was a reason for the survivors to keep in contact with each other, since their future happiness could depend on it. Often work was shared between households, which means that friends and families were depending on each other to survive (Ågren 2013).

\section{Refugees}

One strategy used in war was - and remains - the razing of the enemy's territory, thereby ensuring that the opposing army could not be sustained and was therefore forced to retreat. Such a strategy was damaging to both sides, but perhaps most of all to those farmers living in the contested areas. In the Swedish royal archives, there are several letters where both Karl IX and his successor Gustav II Adolph encouraged their subordinates to "beat, plunder and burn all that you can get your hands on" (original "slå Röfue och bränna alt thet i öfuer komma, "Sari Nauman's translation, in "Swar på Jesper Matzsons skrifuelse" June 29, 1611, in the Royal Register, vol. 113 fol. 301). In February 1612, the then 17-year-old Gustav II Adolf wrote, not without pride, to let his uncle know that he had burned most of Skåne, so that 24 parishes had been reduced to ashes. He promised that he would continue razing the countryside on his retreat ("Till H:F:N: Hertigh Johan [...]" February 13, 1612, in the Royal Register, vol. 115 fol. 67).

The countryside was no place to be during a war. Many of the farmers seem to have fled to the defended towns, putting a strain on those towns' abilities to sustain an increasing population without housing, food or sources of income. As the countryside was devastated, the towns' food sources diminished. The towns were furthermore targets in their own right; the conquering of a town provided the army with a good base for further incursions. If they could not be defended, burning them ahead of a retreat was a better strategy than wasting men and other resources on a hopeless endeavor. Gustav II Adolf obviously had this in mind when he ordered Jesper Matsson first to take Nya Lödöse from the Danes who occupied it, and then if he won it to burn it to the ground so that it could not be used as a fortification in the future (“Till Jesper Matzson [...]” February 26, 1612, in the Royal Register, vol. 115 fol. 83). 
There are also examples of the population being encouraged to leave the frontline, such as when the Danish king Christian II advised the islanders outside of Älvsborg that they were welcome to settle in Denmark or Norway instead of remaining ("Miss. Til Jørgen Daa" November 5, 1611, in Laursen 1916: 438). In this way, the king ensured that the inhabitants would not be turned against the crown, nor supply the enemy lengthening the war.

In addition to direct effects like violence and food shortages, war also had other more long-term impacts. Extant sources allow us only to speculate how any given individual was affected mentally or psychologically by war. On the other hand, we can see how war impacted on towns and their inhabitants. Previously, rulers had tried to evacuate and shut down nearby small towns. After the Northern Seven Years' War, the king appears to have attempted to increase the reduced population of $\mathrm{Ny}$ Varberg, promising any burghers from nearby towns that settled in Ny Varberg at least four years of tax exemptions (cf. Rosén and Carlsson 2013:8; Sandklef 1963:48, 207).

The Danish crown sought to rebuild and repopulate Ny Varberg, and gave firm orders to burghers to rebuild houses on their own plots, which had been deserted because of the war. Still, many years after the end of the war several plots remained empty, the owners of which had been killed or were refugees (Sandklef 1963:163; 166). The remaining burghers seemed to have had financial difficulties and could not pay their town taxes. Still they were not relieved of the obligation to lodge soldiers (Sandklef 1963:164).

\section{Those Who Stayed behind}

One of the major duties of a king was to protect his subjects - he even swore himself to this obligation in his royal oath at the coronation ( $\$ 7$ in Konungsbalken, printed in Holmbäck 1966:5; cf. Nauman 2014:200). That said, the kings of early modern Europe frequently put their subjects at risk in their attempts to conquer new, or at least more, territories. Armies were raised and grew in size all over the continent, putting more and more men to arms, at the same time as those arms were becoming more and more deadly and effective. They were also becoming more costly. The growing armies were financed by new and out-of-the-ordinary forms of taxation as well as loans, thus forcing the respective populaces to pay for the privilege of being protected (Glete 2002). It could have been argued that this was in breach of the king's oath, but such arguments were seldom put forward by subjects. Instead, king and subjects were in agreement that the subjects had a duty to help with the protection if necessary - at least in public (Forssberg 2014).

That said, the king could not always be certain of the loyalty of his subjects. The many wars placed stress on their relationship, and the king and council did their best to convince the subjects that the various wars were just, which according to the definition of the time meant that they were defensive wars and not offensive. Placards and open letters were sent out to all parishes to be read aloud in the churches, explaining the wars to the people and at the same time legitimizing the extraordinary efforts that were demanded of them. All decisions also gained approval by the Riksdag, providing the regents with the people's support, at least on the surface (Forssberg 2011:142; Glete 2002:192-195). 
Special effort was made in securing the loyalty of subjects inhabiting the border areas. In Sweden the same areas were exposed again and again to several of the wars during the seventeenth century: Jämtland in the north, and the provinces of Halland, Skåne, Blekinge, and Småland in the south. The people of these provinces were repeatedly subjected to the hardships of warfare, and used the same strategies to help themselves the best they could. These strategies included mediating separate peace agreements with farmers across the borders (so called "bondefreder") and smuggling people and commodities behind enemy lines ("Öpett Patent, att ingen af E.K:M:ttz. undersåther som wedh Grentzen boo, skole bruka någon handel medh dhe danska" February 15, 1612, in the Royal Register, vol. 115 fol. 70) (Nauman 2014; Persson 2005:248-258).

There are also several examples of subjects swearing oaths to the enemy, and thereby shifting their identity from Swedish to Danish, or vice versa, and from loyal subjects to traitors. The people inhabiting the islands around Älvsborg for example swore their oaths to the Danish king in May 1611, promising to be true and faithful to him and to do their utmost to protect him from danger. The oaths were presented in person, on the king's ship outside of Älvsborg. ("Wij efterschreffne, Louritz Jonssenn paa Asperøenn [...]" May 25, 1611, in DRA: Tyske kancelli, udenrigske afdeling: Sverige 1400-1769: Akter og documenter vedrørande det politiske forhold til Sverige; 1603-1612: 1611-05 Svenska hyldningseder).

As was most often the case, the choice to swear was not a free one. The islanders were threatened by the fleet, and the choice stood between becoming traitors or dead. The commanding officers had different strategies at their hands when trying to win a territory, the most important of course being their strength of arms and men. However, trying to win a territory by arms was a costly matter, to be avoided if possible. Therefore, another strategy was often deployed: persuading the subjects living in the area to swear oaths of allegiance to the conquering enemy. Placards and open letters were sent to the subject and supposedly distributed widely, offering them peace and quiet if only they swore an oath of allegiance. If they refused, they were told, none of the king's promises would be upheld (see for example "Till Almoghen uthi Hallandh om brandskatt at gifue K.M:t" June 21, 1611, in the Royal Register, vol. 113 fol. 296; "Wij Christian den fierde med Guds naade [...]" June 4, 1612; "Wij Christian den fierde med Guds naade [...]" 1612; "Giöre alle witterligt, att wi aff wor synderligh gunst [...]" July 8, 1612, in DRA: Tyske kancelli, udenrigske afdeling; Sverige 14001769; Akter og dokumenter vedrørande det politiske forhold til Sverige; 1603-1612; Belegringen og erobringen af Kalmar og Borgholm 1611-05 - 1611-08-12; Overgivelsen af Elfsborg) (cf. Nauman 2014).

After the Northern Seven Years' War and Danish re-conquest of Varberg in 1569, some inhabitants encountered a new major treachery; first the Swedish conquest, and thereafter by their own Danish king. During the four years the Swedes ruled the castle Varberg, then tried to force farmers in the Varberg region to pay taxes to Sweden as well as swear an oath of loyalty to the Swedish king. Those who felt obliged and did swear the loyalty oath, later explained to the Danish king Fredrik about the coercion, asking for his forgiveness and mercy. The king who had made his promise first, changed his mind just after the re-taking of the castle, and ordered the master of the castle to pursue and even withdraw estates of those nobilities and free farmers who had sworn the Swedish king their loyalty (Sandklef 1963:161). 
Farmers and burghers could thus become traitors during the course of war, but so could also soldiers. In January 1612, the forces of Christian IV, attacked and burned Gamla Lödöse as well as Nya Lödöse and Skara in Swedish county of Västragötland. A large amount of the Danish farmer soldiers deserted on the order of marching into Sweden. Perhaps they feared for their own skin, or perhaps they did not want to ravage and sack their neighboring county (cf. Sandklef 1963:176). There is evidence of "farmers' peaces" during earlier wars, when farmers of warring states decided to stop fighting amongst themselves and instead keep on trading and living in a neighborly fashion (Persson 2005:252-258). During the Kalmar war as well there are indications that the farmers and burghers were more willing to maintain friendly commerce than the kings were (“Öpett Patent” February 15, 1612 in Royal Register vol. 115 fol. 70). Traitors, therefore, could be found in many forms.

\section{Prisoners}

Many enemy soldiers and subjects were killed during wars, others fled. Still others were instead taken as prisoners, some held for ransom whereas others were held as cheap labor. Some prisoners stood out as particularly valuable. These were the ones who held information about the enemy's troops and strategies, and who could be persuaded to reveal that information. The information could be urgent, and there was no time to waste in sending information between places in the midst of war. Therefore, these prisoners were often held captive at the front, or were sent to the place where their information could be of most value. For example, king Gustav II Adolf sent two prisoners to the fortification of Gullberg in February 1612, although this was by no means a safe location, since the prisoners held information that could be valuable to the fight there ("Till Jesper Matzson [...]" February 27, 1612, in the Royal Register, vol. 115, fol. 84). The need to keep the prisoners at the front of the war show the difficulties posed by space-time geographies. It could take several days for a messenger to carry a message between camps, and this time could not be spared.

If the prisoner had a profession that could be used in service of his captors, he might have been given the opportunity to change allegiance and assume a new position. One such opportunity was given a Corporal at Gullberg in 1612 who had fled from the Danish army - in case he wanted to serve the Swedish king instead, Gustav II Adolph would be "well-satisfied" (org. "wäll tillfredz," our translation, in ("Till Jesper Matzson [...]" February 27, 1612, in the Royal Register, vol. 115, fol. 84).

\section{Discussion}

The contexts of landscape, populations and settlements will all impact upon and shape the type of warfare conducted in this setting. For instance, "Urban societies tend to concentrate on urban targets" (Hill and Wileman 2002:144). Both Sweden and Denmark were partly urbanized during early sixteenth century, but the cities were comparably small. The similarities in landscapes perhaps made the two countries adopt similar war strategies (cf. Hill and Wileman 2002:144), as this article also has shown. 
When wanting to conquer enemy land, one strategy would be to save workers in foreign infrastructure and maintain operational agriculture and business (Hill \& Wileman 2002:143). When it comes to the war incidents in the Swedish-Danish border areas, it seems none of the sovereigns acted from this strategy, but rather total devastation was seen as the conquering way.

The social and political topographies of borderlands have long been, and still are, contested arenas for both the respective states and those who dwell on the margins of those respective states.

North of Gothenburg was Norway and to the south was Denmark, which remained in a personal union as two separate kingdoms under successive Danish kings of the House of Oldenburg until the early nineteenth century. During the sixteenth and early seventeenth centuries, villages in these borderlands were subject to harrying and raiding from all three actors, subjecting the local populations to all the vicissitudes which shifting political allegiances do as much as the political and military decisions taken to ensure victories.

While Swedish troops were billeted at Nya Lödöse, Ny Varberg was also having to support a Danish military presence, in addition to more temporary incidences in the immediate vicinity of specific military engagements in the period after1603 until Halland, Bohuslän and Skåne were ceded by Denmark-Norway between 1645 and 1658. This undoubtedly caused any number of problems introducing into the towns and countryside mercenaries in need of food and succor who were beholden to no particular crown. While soldiers were billeted on households in towns, they were also responsible for sacking towns as well as more general pillaging in the countryside for daily survival in the field or razing it as a military tactic. At the same, internal migration within Sweden from Nya Lödöse and Danish Halland from Ny Varberg did little to reduce uncertainty amongst farmers and merchants.

Privileges and tax exemptions were one side of the coin; the threat and actual razing of settlements as well as forced migration also helped shape the social and political topographies of the contested landscapes at the mouth of the Göta and the coasts of Halland and Bohuslän.

As we have discussed, the civilian population bore the brunt of war, whether economically or as refugees or indeed as dead victims. The crowns of Sweden and DenmarkNorway attempted to justify their positions by arguing that theirs was the just war.

The cemeteries at both Ny Varberg and Nya Lödöse have yielded skeletons which evidenced both victims of interpersonal violence concomitant with war as well as those who appear to be victims of execution. Modern archaeological exhumations in Crete, Bosnia, Spain and in Central and South America have contributed much information on such extra-judicial killings which in general are poorly represented in the archaeological record. Unlike modern victims, whom for the most part we can identify or assign to a side in a conflict, we cannot even identify these individuals as Swedish or as Danish-Norwegian. We do not know whether the victims were regarded as traitors or captured enemy soldiers, resisting civilians or punishment killings. Their being extra-judicial killings is even impossible to assert confidently. Nonetheless, we see here evidence for a social landscape which is not stable and subject to the normal functioning of the state at a local level.

Similarly, it is difficult to gain an archaeological insight into the various roles of women during this critical period. The demographic spread of women and men evidenced by the cemetery at Nya Lödöse shows a predominance of males. While we know 
from historical sources that women and men who were craft specialists often shared the workload, archaeological evidence for this often lacks. In the event of a possibly dead husband, permission to remarry was sought from consistory courts. When historical research are shedding new light upon women's role in the unit trains, the historical research material on Nya Lödöse and Ny Varberg have not given us the possibility to look deeper into another often invisible category, children, and their realities during times of unrest. Nor are the experiences of war prisoners easily detected, and to what extent they became integrated in their new context is a question yet to be answered.

Indeed, it is during wartime that we see best the complexities of the social landscape. The local social and political topographies are fluid and unstable, constantly changing subject to external factors such state-level decisions and actors - such as Gustav II Adolf razing Skåne, both literally and figuratively, or Christian II advising the islanders at Älvsborg to move to Denmark or Norway - as well as personal decisions to quit, or indeed to continue to occupy, the frontline. Similarly, soldiers were also required to consider loyalty or life. The breakdown in normality highlights what are the social norms. We can characterize tendencies while nevertheless recognizing the uniqueness of individual actors' various forms of agency. Internal migration is probably more important a factor than external migration, and the return of people such as Adrian Bann and his family to Nya Lödöse in 1619 - after eight years of living in other west Swedish towns - only to be required to move to Gothenburg in 1621 cannot have been unusual.

Clearly as the elite returned, first to Nya Lödöse and later to Gothenburg, such specialists also followed their clientele. Craftsmen undoubtedly followed the citizens as they moved their houses and homes to Älvsborgstaden, Karl IX's Gothenburg and finally Gothenburg. The extent to which they felt themselves Gothenburgers might be inferred from the royal command in 1624 - three years after Gustav II Adolf founded Gothenburg - that all contemporary inhabitants of Nya Lödöse were to move to his new city.

The archaeologies of forced migration and of war are increasingly common topics amongst practitioners of contemporary archaeology. The topics of time, memory, evidence, narrative, history, decay, materiality and ruin are key to an understanding of the effects of the processes of war and forced migration; furthermore, the social and political topographies in which these topics are experienced and how they have a dialectical relationship each effecting change on the other is crucial. Nevertheless, we see these are already taking form in the writing of historical archaeology and in our recreation of its experience in the past.

Open Access This article is distributed under the terms of the Creative Commons Attribution 4.0 International License (http://creativecommons.org/licenses/by/4.0/), which permits unrestricted use, distribution, and reproduction in any medium, provided you give appropriate credit to the original author(s) and the source, provide a link to the Creative Commons license, and indicate if changes were made.

\section{References}

Ågren, M. (2013). Emissaries, allies, accomplices and enemies: married women's work in eighteenth-century urban Sweden. Urban History 41(3).

Almqvist, H. (1929). Göteborgs historia: grundläggingen och de första hundra åren. Skrifter utgivna till Göteborgs stads trehundraårsjubileum genom jubileumsutställningens publikationskommitté. Vol. 2. Göteborg. 
Andersson, J. (2013). Osteologisk rapport av humant skelettmaterial. Karmeliterklostret i Ny Varberg, RAÄ 40:1, Lindberg, Varberg, Hallands län. Högskolan på Gotland, Uppsala universitet.

Balic, I., Brorsson, T., and Öbrink, M. (2015). Halmstad - från köpstad till fästningsstad. In Öbrink, M., ed., Vår by Broktorp. Halmstads äldsta historia. Stiftelsen Hallands Länsmuseer, pp. 7-40.

Carlsson, K. (1992a). Förutsättningar för stadsbebyggelsen och dess utveckling. Chapter 2a. In Persson, B-A., ed., Ny Varberg - staden som blev kungsgård. Stiftelsen Hallands länsmuseer, Halmstad och Varberg, Bröderna Carlssons boktryckeri AB, pp. 13-18.

Carlsson, K. (1992b). Bebyggelsen i Ny Varberg - Inledning. Chapter 3a. In Persson, B-A. ed., Ny Varberg staden som blev kungsgård. Stiftelsen Hallands länsmuseer, Halmstad och Varberg, Bröderna Carlssons boktryckeri AB, pp. 23-24.

Carlsson, K. (1992c). De äldsta spåren av stadsinvånarna. Chapter 3c. In Persson, B-A., ed., Ny Varberg staden som blev kungsgård. Stiftelsen Hallands länsmuseer, Halmstad och Varberg, Bröderna Carlssons boktryckeri AB, pp. 26-32.

Carlsson, K. (1992d). Bebyggelsen växer och regleras omkring år 1500. Chapter 3d. In Persson, B-A., ed., $N y$ Varberg - staden som blev kungsgård. Stiftelsen Hallands länsmuseer, Halmstad och Varberg, Bröderna Carlssons boktryckeri AB, pp. 33-42.

Carlsson, K. (1992e). Bebyggelsen tätnar och växer - staden fullt utbyggd, en storhetstid. Chapter 3e. In Persson, B-A., ed., Ny Varberg - staden som blev kungsgård. Stiftelsen Hallands länsmuseer, Halmstad och Varberg, Bröderna Carlssons boktryckeri AB, pp. 43-56.

Carlsson, K. (1992f). Förändringar i stadsbilden strax före nedläggningen. Chapter 3 f. In Persson, B-A., ed., Ny Varberg - staden som blev kungsgård. Stiftelsen Hallands länsmuseer, Halmstad och Varberg, Bröderna Carlssons boktryckeri AB, pp. 57-60.

Forssberg, A. M. (2011). Arguments of war: Norm and information systems in Sweden and France during the Thirty Years War. In Forssberg, A. M., Hallenberg, M., Husz, O., and Nordin, J. (eds), Organizing history: Studies in honour of Jan Glete. Lund, Nordic Academic Press.

Forssberg, A. M. (2014). The final argument: war and the merging of the military and civilian spheres in 17thcentury Sweden. Scandinavian Journal of History 39(2).

Forsström, M., and Sundnér, B. (1973). De arkeologiska undersökningarna i Ny Varberg 1964-65 och 1968. Varbergs museums årsbok: 93-144.

Glete, J. (2002). War and the state in early modern Europe: Spain, the Dutch Republic and Sweden as fiscalmilitary states, 1500-1600, Routledge, London.

Hansson, K. (1977). Drabbningen i Nya Lödöse 1612. Vikarvet årsbok 1976-77, Bohuslänska fornminnessällskapet Vikarvet.

Hill, P., and Wileman, J. (2002). Landscapes of War: The Archaeology of Aggression and Defence, Tempus, Stroud.

Hjertman M., and Lundberg, L. (forthcoming). Ny Varberg på djupet - ett magasinsarkeologiskt projekt om bortglömda fynd och gamla synder.

Ingelmark, B. E. (1939). The skeletons. In Thordeman, B. ed., Armour from the Battle of Wisby 1361, Stockholm.

Karlsson, A., and Karlsson, A. (2013). Plundringarna i norra Halland under Kalmarkriget 1611-1613. In Wiking-Faria, P., ed., Varbergs fästning och dess roll i Hallands historia. Hallands kulturhistoriska museum, pp. 119-124.

Kjellström, A. (2003). Människorna i slaget - vad benen berättar. In Syse, B. ed., Långfredagsslaget. En arkeologisk historia. Upplandsmuseets skriftserie $\mathrm{Nr} 3$ Uppsala.

Larsson, L and Rosén, C. (forthcoming) "Migration and immigrants in Nya Lödöse 1473-1624".

Laursen, L. (1916). Kancelliets brevbøger vedrørende Danmarks indre forhold, Bd 13, 1609-1615, Kjøbenhavn, Reitzel.

Ling, S. (2011). Genusarbetsdelning i tidigmoderna städer. In Jacobsson, B., and Ågren, M. eds., Levebröd: Vad vet vi om tidigmodern könsarbetsdelning? Swedish Science Press, Uppsala.

Nauman, S. (2014). Winning a war with words: Oaths as means in military conflict in early modern Scandinavia. Scandinavian Journal of History 39(2).

Nauman, S. (2017 forthcoming). Ordens kraft: Politiska eder i Sverige, 1520-1718. Lund, Nordic Academic Press.

Norrie, J., and Gordon, W. (1978). Kalmarkrigen 1611-12, Köpenhamn, Sixtus.

Novak, S. (2000). Battle-related trauma. In Fiorato, V., Boylston, A., and Knüsel, C. (eds.), Blood Red Roses: The Archaeology of a Mass Grave from the Battle of Towton, AD 1461, Oxford.

Oja, L. (2015). Childcare and Gender in Sweden c.1600-1800. Gender and History, 27(1).

Persson, S. (2005). Kungamakt och bonderätt: Om danska kungar och bönder i riket och $i$ Göinge härad ca 1525-1640, Göteborg, Makadam.

Poulain, M., and De Clercq, W. (2015). Exploring an archaeology of the Dutch war of independence in Flanders, Belgium. International Journal of Historical Archaeology 19: 623-646. 
Rosén, C., and Carlsson, K. (2013). En 1700-talstomt i Kungsbacka. Undersökningar på Stortorget i Kungsbacka, Halland, Kungsbacka stad, Stortorget, fornlämning 10. UV Rapport 2013:130, Arkeologisk för- och slutundersökning. Riksantikvarieämbetet.

Sandberg, T. (1966). En odontologisk undersökning av skelettmaterialet från karmeliterklostret i Ny Varberg. Varbergs museums årsbok, pp.: 83-92.

Sandklef, A. (1963). Varbergs historia, Varbergs stad.

Strömbom, S. (1924). Forskningar på platsen för det forna Nya Lödöse (1915-1918). Stadskrönika, grävningsberättelse, fyndkatalog. Skrifter utgivna till Göteborgs stads trehundraårsjubileum. Göteborgs jubileumspublikationer V. Göteborg.

Sveriges krig 1611-1632 (1936). Bd 1, Danska och ryska krigen, Stockholm, Generalstaben.

Ullberg-Loh, K. (1983). En nyupptäckt kapellgrund söder om Ny Varberg. Varbergs museums årsbok: 25-32.

Ullberg-Loh, K. (1992). Hospitalet och S:t Jörgens kapell. Chapter 4. In Persson, B-A. ed., Ny Varberg staden som blev kungsgård. Stiftelsen Hallands länsmuseer, Halmstad och Varberg, Bröderna Carlssons boktryckeri AB, pp. 61-66.

Wiking-Faria, P. (2013). Nordiska sjuårskriget 1563-1570 i Halland. In Wiking-Faria, P. ed., Varbergs fästning och dess roll i Hallands historia. Hallands kulturhistoriska museum, pp. 97-102. 